\title{
Fate of Nutrients, Trace Metals, Bacteria, and Pesticides in Nursery Recycled Water
}

\author{
Yun-Ya Yang, Gurpal S. Toor* \\ Soil and Water Quality Laboratory, Gulf Coast Research and Education Center, Institute of Food and \\ Agricultural Sciences, University of Florida, Wimauma, FL, USA \\ Email: "gstoor@ufl.edu
}

Received 13 February 2015; accepted 2 March 2015; published 4 March 2015

Copyright (C) 2015 by authors and Scientific Research Publishing Inc.

This work is licensed under the Creative Commons Attribution International License (CC BY).

http://creativecommons.org/licenses/by/4.0/

(c) (i) Open Access

\begin{abstract}
Faced with rapid population growth and fresh water scarcity, reuse of reclaimed water is growing worldwide and becoming an integral part of water resource management. Our objective was to determine the fate of nutrients, trace metals, bacteria, and legacy organic compounds (organochlorine pesticides) in the recycled water from five commercial nursery ponds in Florida. The pH of recycled water at all sites was 8.1 - 9.3, except one site (6.5), while the electrical conductivity (EC) was $0.31-0.36 \mathrm{dS} / \mathrm{m}$. Concentrations of trace metals in recycled water were low: Fe $(0.125-0.367$ $\mathrm{mg} / \mathrm{L})$, Al (0.126 - $0.169 \mathrm{mg} / \mathrm{L})$, B (0.104 - $0.153 \mathrm{mg} / \mathrm{L}), \mathrm{Zn}(0.123-0.211 \mathrm{mg} / \mathrm{L})$, and Mn (<0.111 $\mathrm{mg} / \mathrm{L})$. Total phosphorus $(\mathrm{P})$ and total nitrogen $(\mathrm{N})$ in the recycled water were $0.35-1.00 \mathrm{mg} / \mathrm{L}$ and $1.56-2.30 \mathrm{mg} / \mathrm{L}$, respectively. Among organochlorine pesticides, endrin aldehyde was the only pesticide detected in all nursery recycled water ponds, with concentrations from 0.04 to 0.10 $\mu \mathrm{g} / \mathrm{L}$ at four sites and $1.62 \mu \mathrm{g} / \mathrm{L}$ at one site. Other detected pesticides in recycled water were methoxychlor, endosulfan sulfate, dichlorodiphenyldichloroethylene (DDE) and $\alpha$-chlorodane, with concentrations $<0.20 \mu \mathrm{g} / \mathrm{L}$. Total coliforms and Escherichia coli $(E$. coli) in recycled water were 20 50 colony forming units (CFU)/100 $\mathbf{~ m L}$. We conclude that the concentrations of various inorganic and organic compounds in recycled water are very low and do not appear to be problematic for irrigation purposes in Florida's nursery recycled water ponds.
\end{abstract}

\section{Keywords}

Water Quality, Recycled Water, Nutrients, Trace Metals, Pathogen, Pesticides

\section{Introduction}

In the world, $60 \%$ to $90 \%$ of available water is used for agricultural purposes [1]. In the United States, approx-

"Corresponding author. 
imately $80 \%$ of the consumptive water is used in agriculturally related activities [2]. Growing population is increasingly competing with commercial and agricultural uses for limited freshwater supplies. In future, agricultural and other industries may have to heavily rely on using recycled water to meet crop irrigation needs. Water reuse is a growing practice worldwide and Florida leads the United States in using reclaimed or recycled water [3]. Reclaimed water is the domestic wastewater that has received at least secondary treatment and basic disinfection. In Florida, reclaimed water has been safely and successfully used since 1966 [4]. In 1992, Florida produced 1.1 billion liters of reclaimed water per day and this doubled to more than 2.7 billion liters per day by 2013 [5]. The practice of using reclaimed water for irrigation purposes can result in savings of freshwater supplies and can partially supply some nutrients, particularly nitrogen $(\mathrm{N})$ and phosphorus $(\mathrm{P})$. However, there are concerns about the impact of the quality of the reclaimed water on crops, soils, and irrigation systems.

Recycling ponds are often regarded as a best management practice for eliminating potential problems that arise from container nursery runoff [6]. Chemicals runoff from nursery production facilities is a concern because it is a potential nonpoint source of pollution. Runoff of residential chemicals may be considerable in some situations [7]-[9]. For example, a six-state survey of container nurseries found that nitrate- $\mathrm{N}\left(\mathrm{NO}_{3}-\mathrm{N}\right)$ levels in runoff, irrigation ponds and wells exceeded the US Environmental Protection Agency's (US EPA) drinking water limit of $10 \mathrm{mg} / \mathrm{L}[10]$.

Due to the continuous reuse, water in the nursery recycling ponds can contain high concentrations of nutrients and soluble salts and may also contain trace metals, pathogens, and pesticides. The presence of excess amounts of these constituents in recycled water may have adverse effects on plant growth and environment, if runoff water reaches water bodies of concern [8] [10]. Therefore, it is important to know if the recycled water contains harmful compounds in excessive amounts, and if so, what mitigation approaches are needed to remove these compounds from the recycled water, so that it can be continuously used in an environmentally sustainable way. In addition, monitoring of physical, chemical, and biological variables in recycled water is necessary to ensure acceptable water quality. The results from a survey in greenhouse and nursery irrigation water highlighted that monitoring of physical, chemical, and biological water quality can be used to improve irrigation system design when implementing a water treatment technology [11].

As in other parts of the world, nursery and landscape industry in Florida is currently facing the challenge of managing an economically important sector in an environmentally-sustainable way. It is important to be proactive to find if there are any concerns related to the presence of chemical compounds in the recycled water and if so develop approaches to alleviate those concerns. Documenting the safe use of recycled water will be of significant benefit to not only assure the sustainability of agricultural practices but also assure future environmental compliance. Thus, the overall goal of this study was to determine the fate of major water quality constituents in nursery recycled water. The specific objective was to characterize salinity, nutrients, trace metals, bacteria, and pesticides in recycled water samples from five commercial nurseries in Florida that represented diversity in plant species production and management practices.

\section{Materials and Methods}

\subsection{Site Description}

Five commercial (working) nurseries with a recycled pond were used for this study. The recycled ponds in these nurseries receive any water leaving the property (nursery site) following a significant rainfall and/irrigation event. All nurseries were located in the Hillsborough County, which drains into the Tampa Bay Watershed in the west coast of Florida. Due to the confidentiality agreement signed with the nursery growers, we cannot disclose the names and specific locations of nurseries. The county has an area of $2714 \mathrm{~km}^{2}$. Of that area more than $84 \%$ $\left(2350 \mathrm{~km}^{2}\right)$ is unincorporated. The Hillsborough County land use/land cover consists of about $46 \%$ urban and built up, $19 \%$ agriculture and $17 \%$ wetlands. The remaining $18 \%$ is designated as recreational, open land, rangelands, upland forests, water and other uses [12].

\subsection{Sample Collection}

Water samples were collected from five commercial nursery ponds in April 2010 from 8 a.m. to 12 p.m. Three of the ponds were located within one nursery and two ponds were located at two other nurseries. The climate in the area is subtropical, with an average annual air temperature of $22^{\circ} \mathrm{C}$ and daily extremes ranging from $0.7^{\circ} \mathrm{C}$ to $35^{\circ} \mathrm{C}$ and total rainfall varies from 120 to $130 \mathrm{~cm}$ per year. 
Water samples were collected using a long-handled polyethylene $500 \mathrm{~mL}$ capacity dipper (SCIENCEWARE®). Samples for organochlorine pesticide analysis were collected in 1-L amber glass bottles (Fisher Scientific, Fair Lawn, NJ). Samples for nutrients, trace metals, and bacteria were collected in separate $250 \mathrm{~mL}$ high-density polyethylene (HDPE) bottles (Fisher Scientific, Fair Lawn, NJ). All samples were stored at $4^{\circ} \mathrm{C}$ until analysis. At each pond, samples were also analyzed in-situ for $\mathrm{pH}$, electrical conductivity (EC), temperature, and dissolved oxygen (DO) using a Manta Water Quality Multiprobe (Eureka Environmental Engineering, Austin, TX).

\subsection{Sample Preparation and Analysis}

\subsubsection{Nutrients, Cations, and Trace Metals}

Approximately $100 \mathrm{~mL}$ of each collected water sample was preserved with concentrated $\mathrm{H}_{2} \mathrm{SO}_{4}$ or $\mathrm{HNO}_{3}$ at $\mathrm{pH}$ 2 for total $\mathrm{P}$ and trace metals analysis, respectively. Samples filtered through $0.45-\mu \mathrm{m}$ filter paper were analyzed for chloride $\left(\mathrm{Cl}^{-}\right)$and ammonium- $\mathrm{N}\left(\mathrm{NH}_{4}-\mathrm{N}\right)$ and nitrate/nitrite- $\mathrm{N}\left(\mathrm{NO}_{\mathrm{x}}-\mathrm{N} ; \mathrm{NO}_{2}^{-}+\mathrm{NO}_{3}^{-}\right)$using an Automated Discrete Analyzer (AQ2+, Seal Analytical Inc., Mequon, WI) with EPA method 325.2 [13] and 350.1 [14], respectively. Total $\mathrm{N}$ was determined in unfiltered water samples using alkaline persulfate digestion method [15] and then analyzed for $\mathrm{NO}_{\mathrm{x}}-\mathrm{N}$ as above. Organic $\mathrm{N}$ was calculated as the difference between total $\mathrm{N}$ and $\left(\mathrm{NH}_{4}-\mathrm{N}+\mathrm{NO}_{\mathrm{x}}-\mathrm{N}\right)$. Preserved water samples were analyzed for total $\mathrm{P}$, cations, and trace metals including aluminum $(\mathrm{Al})$, boron $(\mathrm{B})$, calcium $(\mathrm{Ca})$, copper $(\mathrm{Cu})$, iron $(\mathrm{Fe})$, potassium $(\mathrm{K})$, magnesium $(\mathrm{Mg})$, manganese $(\mathrm{Mn})$, molybdenum (Mo), sodium ( $\mathrm{Na})$, and zinc (Zn) using an inductively coupled plasma-optical emission spectrometer (ICP-OES; PerkinElmer Optima 2100 DV; PerkinElmer, Shelton, CT) according to EPA method $6010 \mathrm{C}[16]$.

\subsubsection{Pesticides}

Organochlorine pesticides analysis was conducted using EPA Method $3510 \mathrm{C}$ [17]. In brief, 1 L of sample was extracted with $60 \mathrm{~mL}$ of methylene chloride (Fisher Scientific, Fair Lawn, NJ) three times in 2-L separatory funnel. Sample bottles were extracted rinsed with methylene chloride to recover any adsorbed analyte. The separatory funnel was sealed and shaken vigorously for $2 \mathrm{~min}$ and allowed to settle. After complete separation, the organic phase was drained by centrifugation at $3000 \mathrm{rpm}$ for $5 \mathrm{~min}$ (Sorvall Legend RT, Thermo Scientific), while the aqueous phase was re-extracted. The extracted organic phase was combined and concentrated to $1 \mathrm{~mL}$ using a Caliper Life Sciences Turbo Vap II Concentration Evaporator (Turbo Vap II, Zymark Inc.). Samples were then transferred onto a Resprep Florisil cartridge $(3 \mathrm{~mL}, 250 \mathrm{mg}$ ), and eluted with $50 \mathrm{~mL}$ of hexane (Fisher Scientific, Fair Lawn, NJ). The eluent was collected and evaporated to $5 \mathrm{~mL}$ and analyzed with a gas chromatographyelectron capture detector (GC-ECD) system.

A PerkinElmer Clarus $500 \mathrm{GC}$ together with a Restek Rtx-CL Pesticides column $(30 \mathrm{~m} \times 0.32 \mathrm{~mm}$ id $\times 0.5 \mu \mathrm{m}$; Restek Corp, USA) was used for the separation and analysis of the following organochlorine pesticides: aldrin, $\alpha$-hexachlorocyclohexane (HCH), $\beta$-HCH, $\gamma$-HCH, $\delta$-HCH, $\alpha$-chlordane, $\gamma$-chlordane, 4,4'-dichloro-di-phenyldichloroethane (DDD), 4,4'-dichloro-diphenyl-dichloroethylene (DDE), 4,4'-dichloro-diphenyl-trichloroethane (DDT), dieldrin, endosulfan I, endosulfan II, endosulfan sulfate, endrin, endrin aldehyde, endrin ketone, heptachlor, heptachlor epoxide, and methoxychlor. The surrogates used were 2, 4, 5, 6-tetrachloro-mxylene (TCMX) and decachlorobiphenyl (DCB). The temperature of injector and detector were $250^{\circ} \mathrm{C}$ and $425^{\circ} \mathrm{C}$, respectively. The column temperature program was as follows: initial temperature $100^{\circ} \mathrm{C}$ held for $2 \mathrm{~min}$, ramped to $200^{\circ} \mathrm{C}$ at $45^{\circ} \mathrm{C} \mathrm{min}{ }^{-1}$, and held for $1 \mathrm{~min}$. The oven temperature was then ramped to $300^{\circ} \mathrm{C}$ at $15^{\circ} \mathrm{C} \mathrm{min}^{-1}$ and held for 3 min. The column pressure was held at 25 psi (helium) and the sample was injected in a splitless mode. Confirmation of the chlorinated pesticides was done by running the same samples on a Rtx-CL Pesticides 2 column $(30 \mathrm{~m} \times 0.25 \mathrm{~mm}$ id $\times 0.2 \mu \mathrm{m}$; Restek Corp., USA) under slightly different conditions. The slight adjustment to the temperature program was made to optimize peak splitting between $\delta$ - $\mathrm{HCH}$ and heptachlor. The changes that were made were to the final oven temperature ramp from $300^{\circ} \mathrm{C}$ at $15^{\circ} \mathrm{C} \mathrm{min}^{-1}$, held for $3 \mathrm{~min}$ to $325^{\circ} \mathrm{C}$ at $8.5^{\circ} \mathrm{C}$ $\mathrm{min}^{-1}$ and held for $2 \mathrm{~min}$. Another change was that the column pressure was held at 11 psi throughout the run.

\subsubsection{Total Coliforms and Escherichia coli}

Total coliforms and Escherichia coli (E. coli) concentrations in pond waters were quantified via membrane filtration on MI agar BBLTM (Becton Dickinson) using EPA method 1604 [18]. 


\section{Results and Discussion}

\subsection{Basic Properties of Recycled Water}

The $\mathrm{pH}$ is an important characteristic of water when considering reuse of recycled water for irrigation. It is well documented that the ideal $\mathrm{pH}$ for most plant production is $5.0-6.5$ as this provides a balance of availability of essential plant nutrients [19]. The $\mathrm{pH}$ of recycled water at four sites was alkaline $(8.1-9.3)$ and one site had neutral $\mathrm{pH}$ (6.5) (Table 1). In general, the measured values of $\mathrm{pH}$ were within the EPA recommended range (6 9) of water reuse for irrigation [20]. The $\mathrm{pH}$ values from sites $\mathrm{C}$ and $\mathrm{D}$ were slightly higher than the upper limit of the recommended range.

Electrical conductivity (EC) is directly related to the concentration of dissolved ions in the water. The EC values at all sites were $0.311-0.362 \mathrm{dS} / \mathrm{m}$, which was equivalent to $199-232 \mathrm{mg} / \mathrm{L}$ of total dissolved solids (TDS; Table 1). The EC and TDS levels were well below the EPA limits of $<2.0 \mathrm{dS} / \mathrm{m} \mathrm{EC}$ and $500-2000 \mathrm{mg} / \mathrm{L}$ TDS in the irrigation water for nursery crops [20]. The water temperature in the ponds fluctuated from $21.4^{\circ} \mathrm{C}$ to $25.3^{\circ} \mathrm{C}$ at the sampling time. Other chemical properties of the recycled water included $2-12 \mathrm{mg} / \mathrm{L} \mathrm{DO}, 23 \%$ $145 \%$ saturated DO, and $9.2-25.8 \mathrm{mg} / \mathrm{L} \mathrm{Cl}^{-}$(Table 1); these values are in fact better than the typical values found in most stream waters, suggesting that the recycled water is of good quality.

\subsection{Concentrations of Cations in Recycled Water}

Total cations concentrations in the recycled water ranged from 62.7 to $84.3 \mathrm{mg} / \mathrm{L}$; of which, $\mathrm{Ca}^{2+}$ was the dominant cation accounting for $52 \%-73 \%(39.3-55.3 \mathrm{mg} / \mathrm{L})$ (Table 2). The concentration of other cations, i.e., $\mathrm{Mg}^{2+}, \mathrm{K}^{+}$, and $\mathrm{Na}^{+}$were $5-11.5,4.4-16.7$, and $6.2-18.5 \mathrm{mg} / \mathrm{L}$, respectively.

\subsection{Concentrations of Trace Metals in the Recycled Water}

Concentrations of $\mathrm{Fe}, \mathrm{Al}, \mathrm{Zn}, \mathrm{B}$, and $\mathrm{Mn}$ were less than $0.4 \mathrm{mg} / \mathrm{L}$ in all pond waters (Table 3). Copper $(\mathrm{Cu})$ and

Table 1. Selected physical and chemical properties (mean \pm standard deviation) of nursery recycled water $(n=4)$.

\begin{tabular}{cccccccc}
\hline Site & $\mathrm{pH}$ & $\mathrm{EC}(\mathrm{dS} / \mathrm{m})$ & $\mathrm{TDS}^{\mathrm{a}}(\mathrm{mg} / \mathrm{L})$ & $\mathrm{Cl}^{-}(\mathrm{mg} / \mathrm{L})$ & $\mathrm{DO}(\mathrm{mg} / \mathrm{L})$ & Saturated DO $(\%)$ & Temperature $\left({ }^{\circ} \mathrm{C}\right)$ \\
\hline A & $8.9 \pm 0.12$ & $0.33 \pm 0.0024$ & $211 \pm 1.5$ & 11.3 & $7.8 \pm 1.08$ & $95 \pm 13.9$ & $25.3 \pm 0.19$ \\
B & $8.1 \pm 0.19$ & $0.311 \pm 0.008$ & $199 \pm 0.5$ & 13.2 & $7.1 \pm 0.19$ & $86 \pm 2.4$ & $25.3 \pm 0.12$ \\
C & $9.3 \pm 0.04$ & $0.328 \pm 0.0012$ & $210 \pm 0.7$ & 12.6 & $7.2 \pm 0.27$ & $87 \pm 4.1$ & $25.2 \pm 0.12$ \\
D & $9.1 \pm 0.22$ & $0.362 \pm 0.0085$ & $232 \pm 5.4$ & 25.8 & $12.0 \pm 1.6$ & $145 \pm 20$ & $24.5 \pm 0.71$ \\
E & $6.5 \pm 0.08$ & $0.317 \pm 0.001$ & $203 \pm 0.6$ & 9.2 & $2.0 \pm 0.25$ & $23 \pm 2.7$ & $21.4 \pm 0.23$ \\
\hline
\end{tabular}

${ }^{\mathrm{a}}$ Total dissolved salts $(\mathrm{EC}(\mathrm{dS} / \mathrm{m}) \times 640)$.

Table 2. Concentrations of cations in nursery recycled water ${ }^{\mathrm{a}}$.

\begin{tabular}{cccccc}
\hline Site & $\mathrm{Ca}^{2+}(\mathrm{mg} / \mathrm{L})$ & $\mathrm{Mg}^{2+}(\mathrm{mg} / \mathrm{L})$ & $\mathrm{K}^{+}(\mathrm{mg} / \mathrm{L})$ & $\mathrm{Na}^{+}(\mathrm{mg} / \mathrm{L})$ & Total cations $(\mathrm{mg} / \mathrm{L})$ \\
\hline A & $40.1(56)$ & $11.5(16)$ & $9.1(13)$ & $10.7(15)$ & 71.3 \\
B & $39.6(59)$ & $9.1(13)$ & $8.3(12)$ & $10.6(16)$ & 67.6 \\
C & $39.3(52)$ & $8.8(12)$ & $16.7(22)$ & $11.4(15)$ & 76.2 \\
D & $55.3(66)$ & $5.0(6)$ & $5.5(7)$ & $18.5(22)$ & 84.3 \\
E & $45.9(73)$ & $6.3(10)$ & $4.4(7)$ & $6.2(10)$ & 62.7 \\
\hline
\end{tabular}

${ }^{\mathrm{a}}$ Values in parentheses are percent of total cations.

Table 3. Concentrations of metals in nursery recycled water.

\begin{tabular}{cccccc}
\hline Site & $\mathrm{Fe}(\mathrm{mg} / \mathrm{L})$ & $\mathrm{Al}(\mathrm{mg} / \mathrm{L})$ & $\mathrm{Zn}(\mathrm{mg} / \mathrm{L})$ & $\mathrm{B}(\mathrm{mg} / \mathrm{L})$ & $\mathrm{Mn}(\mathrm{mg} / \mathrm{L})$ \\
$\mathrm{A}$ & $-^{\mathrm{a}}$ & 0.169 & 0.149 & - & - \\
$\mathrm{B}$ & 0.180 & 0.177 & 0.211 & 0.153 & - \\
$\mathrm{C}$ & - & 0.126 & 0.123 & 0.138 & - \\
$\mathrm{D}$ & 0.125 & 0.149 & 0.154 & 0.104 & - \\
$\mathrm{E}$ & 0.367 & - & 0.162 & - & 0.111 \\
\hline
\end{tabular}

\footnotetext{
${ }^{\mathrm{a}}$ Not detected.
} 
Mo were not detected in any of the samples. Values of detected trace metals were below EPA's recommended range of reclaimed water quality for irrigation (i.e., $5 \mathrm{mg} / \mathrm{L}$ of Al and Fe; $0.2 \mathrm{mg} / \mathrm{L}$ of Cu and $\mathrm{Mn} ; 2 \mathrm{mg} / \mathrm{L}$ of Zn) [20].

\subsection{Concentrations of Nitrogen and Phosphorus Forms in the Recycled Water}

Total $\mathrm{N}$ concentrations in the recycled water were $1.56-2.30 \mathrm{mg} / \mathrm{L}$; of which, $78 \%$ to $98 \%$ was organic $\mathrm{N}(1.42$ $1.88 \mathrm{mg} / \mathrm{L}$ ) with the remainder $(2 \%-22 \%)$ being in inorganic $\mathrm{N}$ forms such as $\mathrm{NO}_{3}-\mathrm{N}+\mathrm{NO}_{2}-\mathrm{N}$ (not detected, $\mathrm{ND}-0.35 \mathrm{mg} / \mathrm{L})$, and $\mathrm{NH}_{4}-\mathrm{N}(0.03-0.37 \mathrm{mg} / \mathrm{L}$; Table 4). Total Kjeldahl $\mathrm{N}(\mathrm{TKN})$ ranged from 1.47 to 2.17 $\mathrm{mg} / \mathrm{L}$. The $\mathrm{NH}_{4}-\mathrm{N}$ concentration at site $\mathrm{E}$ was 10 times greater than other sites likely due to the low DO level as compared to other sites (see Table 4). The less aerobic conditions (i.e., low DO) present at the site $\mathrm{E}$ may have reduced the oxidation of $\mathrm{NH}_{4}^{+}$to $\mathrm{NO}_{3}^{-}$, resulting in higher $\mathrm{NH}_{4}^{+}$concentrations. Across all sites, concentrations of $\mathrm{NH}_{4}-\mathrm{N}$ were inversely correlated $(R=-0.86)$ with DO.

Total P concentrations were $0.59-1.00 \mathrm{mg} / \mathrm{L}$ in the recycled water, of which, $87 \%-96 \%$ was present as soluble inorganic $\mathrm{P}\left(\mathrm{PO}_{4}-\mathrm{P}, 0.32-0.94 \mathrm{mg} / \mathrm{L}\right)$ with the remainder $(4 \%-13 \%)$ as organic $\mathrm{P}$ forms (Table 4).

\subsection{Concentrations of Pesticides in Recycled Water}

Five legacy organochlorine pesticides were detected in the recycled water, with concentrations below $2 \mu \mathrm{g} / \mathrm{L}$ (Table 5). Among the analyzed pesticides, endrin aldehyde $(0.044-1.619 \mu \mathrm{g} / \mathrm{L})$ was detected at all sites. Methoxychlor (ND-0.193 $\mu \mathrm{g} / \mathrm{L}$ ) and endosulfan sulfate (ND-0.157 $\mu \mathrm{g} / \mathrm{L}$ ) were found at three and two sites, respectively. Alpha-chlordane (ND-0.046 $\mu \mathrm{g} / \mathrm{L}$ ) and DDE (ND-0.053 $\mu \mathrm{g} / \mathrm{L}$ ) were only found at one site. These organochlorine pesticides found in pond waters may have been due to the past usage as most of them were banned in the United States in the 1970s. The past usage of these pesticides likely resulted in presence of these in the pond waters with eroded soil particles.

\subsection{Total Coliform and Escherichia coli in the Recycled Water}

Total coliform and E. coli concentrations in recycled water were $22-47$ and $20-35 \mathrm{CFU} / 100 \mathrm{~mL}$, respectively (Figure 1). These values of total coliform and E. coli were within the safe range recommended by EPA $(<1000$ CFU/100 mL) [20]. Low values of total coliforms in recycled water, which can be used as an indicator of total load of pathogens, suggests a negligible risk of spreading of plant diseases with reclaimed water irrigation.

Table 4. Concentrations of nitrogen and phosphorus forms in nursery recycled water.
\begin{tabular}{cccccccc}
\hline Site & $\begin{array}{c}\mathrm{NO}_{2}-\mathrm{N}+\mathrm{NO}_{3}-\mathrm{N} \\
(\mathrm{mg} / \mathrm{L})\end{array}$ & $\mathrm{NH}_{4}-\mathrm{N}(\mathrm{mg} / \mathrm{L})$ & Organic $\mathrm{N}(\mathrm{mg} / \mathrm{L})$ & $\mathrm{TKN}(\mathrm{mg} / \mathrm{L})$ & $\begin{array}{c}\mathrm{Total} \mathrm{N} \\
(\mathrm{mg} / \mathrm{L})\end{array}$ & $\begin{array}{c}\mathrm{PO}_{4}-\mathrm{P} \\
(\mathrm{mg} / \mathrm{L})\end{array}$ & $\begin{array}{c}\mathrm{Total} \mathrm{P} \\
(\mathrm{mg} / \mathrm{L})\end{array}$ \\
\hline $\mathrm{A}$ & $0.35(15)^{\mathrm{a}}$ & $0.04(2)^{\mathrm{a}}$ & $1.88(83)^{\mathrm{a}}$ & 1.92 & 2.26 & $0.51(87)^{\mathrm{b}}$ & 0.59 \\
$\mathrm{~B}$ & $0.10(7)$ & $0.05(3)$ & $1.42(90)$ & 1.47 & 1.57 & $0.32(92)$ & 0.35 \\
$\mathrm{C}$ & $0.07(3)$ & $0.07(3)$ & $1.85(93)$ & 1.92 & 1.98 & $0.94(94)$ & 1.00 \\
$\mathrm{D}$ & $-^{\mathrm{c}}$ & $0.03(2)$ & $1.53(98)$ & 1.56 & 1.56 & $0.48(89)$ & 0.54 \\
$\mathrm{E}$ & $0.13(6)$ & $0.37(16)$ & $1.80(78)$ & 2.17 & 2.30 & $0.70(96)$ & 0.73 \\
\hline
\end{tabular}

${ }^{\mathrm{a}}$ Values in parentheses are percent of total $\mathrm{N} ;{ }^{\mathrm{b}}$ Values in parentheses are percent of total $\mathrm{P} ;{ }^{\mathrm{c}}$ Not detected.

Table 5. Concentrations of five detected organochlorine pesticides in nursery recycled water.

\begin{tabular}{cccccc}
\hline Site & Endrin aldehyde $(\mu \mathrm{g} / \mathrm{L})$ & Methoxychlor $(\mu \mathrm{g} / \mathrm{L})$ & Endosulfan sulfate $(\mu \mathrm{g} / \mathrm{L})$ & DDE $(\mu \mathrm{g} / \mathrm{L})$ & $\alpha-\mathrm{Chlordane}(\mu \mathrm{g} / \mathrm{L})$ \\
\hline A & 1.619 & 0.193 & 0.014 & 0.053 & - \\
B & 0.078 & - & 0.157 & - & - \\
C & 0.044 & 0.078 & - & - & - \\
D & 0.082 & 0.035 & - & - \\
E & 0.102 & & - \\
\hline
\end{tabular}

${ }^{\mathrm{a}}$ Not detected. 


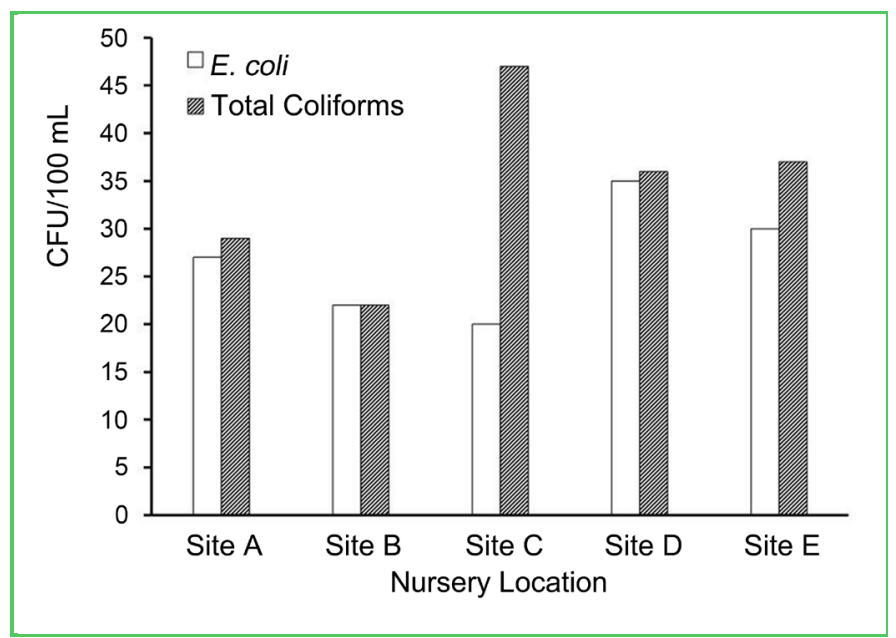

Figure 1. Total coliforms and E. coli in nursery recycled water.

\section{Conclusion}

Characterization of recycled water from commercial nurseries can aid in understanding if there are any contaminants of concern in recycled water for plant productivity and for environmental pollution if excess runoff leaves the nursery sites. Our data show that recycled water from nursery ponds is of good quality with low levels of nutrients, trace metals, bacteria, and legacy pesticides. Low levels of nutrients and trace metals in recycled water can still be beneficial for the plants, as many of these are essential elements for plant growth and productivity. Organic $\mathrm{N}$ and soluble inorganic $\mathrm{P}$ are the dominant forms of nutrients in recycled water. The presence of high organic $\mathrm{N}$ in nursery ponds shows that $\mathrm{N}$ is efficiently cycled in the ponds. These results indicate that recycled water in nursery ponds is not polluted and the risk of spreading of plant diseases in nurseries using reclaimed water is negligible.

\section{Acknowledgements}

We are thankful to Florida Nursery Growers and Landscape Association (FNGLA) for providing funding for this research work and nursery growers for allowing access to the recycled water ponds.

\section{References}

[1] Oron, G., Gillerman, L., Buriakovsky, N., Bick, A., Gargir, M., Dolan, Y., Manor, Y., Katz, L. and Hagin, J. (2008) Membrane Technology for Advanced Wastewater Reclamation for Sustainable Agriculture Production. Desalination, 218, 170-180. http://dx.doi.org/10.1016/j.desal.2006.09.033

[2] US Department of Agriculture (2013) Economic Research Service: Irrigation \& Water Use. http://www.ers.usda.gov/topics/farm-practices-management/irrigation-water-use.aspx\#.U--cdPldV4g

[3] Parsons, L.R., Sheikh, B., Holden, R. and York, D.W. (2010) Reclaimed Water as an Alternative Water Source for Crop Irrigation. HortScience, 45, 1626-1629.

[4] Southwest Florida Water Management District (SFWMD) (2009) Reclaimed Water: A Reliable, Safe Alternative Water Supply. https://www.watereuse.org/files/s/docs/reclaimed water lev2 08 09.pdf

[5] Florida Department of Environmental Protection (FDEP) (2014) 2013 Reuse Inventory. Florida Department of Environmental Protection, Tallahassee, Florida. http://www.dep.state.fl.us/water/reuse/docs/inventory/2013 reuse-report.pdf

[6] Fain, G.B., Gilliam, C.H., Tilt, K.M., Oliver, J.W. and Wallace, B. (2000) Survey of Best Management Practices in Container Production Nurseries. Journal of Environmental Horticulture, 18, 142-144.

[7] Ristvey, A.G., Lea-Cox, J.D. and Ross, D.S. (2004) Nutrient Uptake, Partitioning and Leaching Losses from Container-Nursery Production Systems. Acta Horticulturae, 630, 321-328.

[8] Mangiafico, S.S., Gan, J., Wu, L.S., Lu, J.H., Newman, J.P., Faber, B., Merhaut, D.J. and Evans, R. (2008) Detention and Recycling Basins for Managing Nutrient and Pesticide Runoff from Nurseries. HortScience, 43, 393-398. 
[9] Colangelo, D.J. and Brand, M.H. (2001) Nitrate Leaching Beneath a Containerized Nursery Crop Receiving Trickle or Overhead Irrigation. Journal of Environmental Quality, 30, 1564-1574. http://dx.doi.org/10.2134/jeq2001.3051564x

[10] Yeager, T., Wright, R., Fare, D., Gilliam, C., Johnson, J., Bilderback, T. and Zondag, R. (1993) Six State Survey of Container Nursery Nitrate Nitrogen Runoff. Journal of Environmental Horticulture, 11, 206-208.

[11] Meador, D.P., Fisher, P.R., Harmon, P.F., Peres, N.A., Teplitski, M. and Guy, C.L. (2012) Survey of Physical, Chemical, and Microbial Water Quality in Greenhouse and Nursery Irrigation Water. HortTechnology, 22, 778-786.

[12] Hillsborough Community Atlas (2014)

http://www.hillsborough.communityatlas.usf.edu/general/default.asp?ID=12057\&level=cnty.

[13] US Environmental Protection Agency (1983) Method 325.2. Chloride by Automated Colorimetry. Methods for the Chemical Analysis of Water and Wastes (MCAWW). http://www.caslab.com/EPA-Methods/PDF/EPA-Method-3252.pdf

[14] US Environmental Protection Agency (1993) Method 350.1. Determination of Ammonia Nitrogen by Semi-Automated Colorimetry. Environmental Monitoring Systems Laboratory, Office of Research and Development, USEPA, Cincinnati. http://water.epa.gov/scitech/methods/cwa/bioindicators/upload/2007_07_10_methods_method_350_1.pdf

[15] Ebina, J., Tsutsui, T. and Shirai, T. (1983) Simultaneous Determination of Total Nitrogen and Total Phosphorus in Water Using Peroxodisulfate Oxidation. Water Research, 17, 1721-1726. http://dx.doi.org/10.1016/0043-1354(83)90192-6

[16] US Environmental Protection Agency (2007) Method 6010 C (SW-846). Inductively Coupled Plasma-Atomic Emission Spectrometry, Revision 3. http://www.epa.gov/osw/hazard/testmethods/sw846/pdfs/6010c.pdf

[17] US Environmental Protection Agency (1996) Method 3510C. Separatory Funnel Liquid-Liquid Extraction, Revision 3. http://www.epa.gov/osw/hazard/testmethods/sw846/pdfs/3510c.pdf

[18] US Environmental Protection Agency (2002) Method 1604. Total Coliforms and Escherichia coli in Water by Membrane Filtration Using a Simultaneous Detection Technique (MI Medium). Rept. Mo. EPA 821-R-02-024, Environmental Protection Agency, Washington DC. http://www.epa.gov/microbes/documents/1604sp02.pdf

[19] Ghehsareh, A.M. and Samadi, N. (2012) Effect of Soil Acidification on Growth Indices and Microelements Uptake by Greenhouse Cucumber. African Journal of Agricultural Research, 7, 1659-1665.

[20] US Environmental Protection Agency (2004) Guideline for Water Reuse. EPA 645-R-04-108, Environmental Protection Agency, Washington DC. http://water.epa.gov/aboutow/owm/upload/Water-Reuse-Guidelines-625r04108.pdf 